\title{
Producing a successful PhD thesis
}

\section{David Barrett $\odot,{ }^{1}$ Alison Rodriguez $\left(1,,^{2}\right.$ Joanna Smith ${ }^{3}$}

10.1136/ebnurs-2020-103376

${ }^{1}$ Faculty of Health Sciences, University of Hull, Hull, UK

${ }^{2}$ School of Healthcare, University of Leeds, Leeds, UK

${ }^{3}$ School of Healthcare, University of Leeds, Leeds, UK

\section{Correspondence to:}

Dr David Barrett, Faculty of

Health Sciences, University of Hull, Hull HU6 7RX, UK; D.I. Barrett@hull.ac.uk
All doctoral students strive for the day-after years of often all-consuming study-that their thesis is ready to submit. For both doctoral students and supervisors there is often trepidation about whether the thesis will meet the criteria to merit the award of a Doctor of Philosophy $(\mathrm{PhD})$. As anxieties increase, doctoral students often ask what makes a good $\mathrm{PhD}$, something we explored in a recent 'Research Made Simple' article, ${ }^{1}$ but perhaps the more important question is 'what makes a $\mathrm{PhD}$ student successful?' In this article we outline the core criteria on which $\mathrm{PhD}$ theses are judged and offer suggestions for achieving success.

\section{How are PhDs assessed}

Traditionally, a PhD involves 3 to 4 years of full-time study (or a longer part-time programme), which is assessed by the student submitting the work they have undertaken as a thesis or-less commonly-a portfolio of published papers and an associated narrative (sometimes referred to as 'PhD by publication'). In addition, the student must undertake an oral defence of their work through a discussion (the 'viva') with examiners, who are deemed to be experts in the field of study or with related methodological expertise. ${ }^{2}$

A thesis is a self-contained monograph written by the student which:

1. Sets out the problem and context of the research, including theoretical perspectives.

2. Outlines existing approaches that have addressed the problem or related issues before, typically by undertaking a thorough critical analysis of literature and identifying a gap in the evidence.

3. Justifies and critically evaluates the research methodologies and methods chosen to address the problem.

4. Presents the finding of the research and how they add to existing knowledge.

5. Makes recommendations as to how the findings can advance the discipline and improve practice, and/or suggest further research directions.

\section{What criteria are used to assess a PhD thesis?}

The core criteria for PhD success-ubiquitous to all disciplines and universities-are that the student;

1. Has made an original and significant contribution to knowledge of the topic under investigation;

2. Draws on a well-argued and cohesive conceptual/ theoretical framework;

3. Demonstrates the ability to critically evaluate and justify the research methodology and methods adopted;

4. Can convey information (written and verbally) succinctly;

5. Produces a thesis is of sufficient rigour that the work is evaluated as publishable in relevant disciplinespecific journal(s).

Table 1 highlights some of the key ingredients of $\mathrm{PhD}$ success, in terms of the study, thesis and viva.

\section{Justifying methods}

The justification of methodological choices is usually presented in a distinct chapter that typically has two components: first, a 'big picture' description of the theoretical perspective and methodological justification (sometimes called the research approach), followed by an account of procedure (methods) of how the research was undertaken.

\section{Critical writing}

An essential criterion expected from examiners is that students demonstrate criticality in the way they present and defend information. This can be a challenge, and many $\mathrm{PhD}$ students perceive that there is little guidance about how to develop effective arguments and few opportunities to develop critical writing skills. ${ }^{23}$ Similar to developing knowledge and understanding of research methods, students need the knowledge and skills for effective oral communication of ideas and writing. ${ }^{3}$

The student must be able to write succinctly and critically to produce a robust and coherent thesis. ${ }^{2}{ }^{4} \mathrm{~A}$ thesis should open with a clear outline of the problem, informing the reader what the thesis about and why the topic is important. It should detail what contexts and perspectives are relevant and offer an outline to the layout of the thesis. In all chapters, students should consider the following:

- Use of 'signposts' to tell the reader where they are going to go, summarising afterwards and providing appropriate links throughout.

- Meaningful headings: the content of chapters and sections need to reflect the heading.

- Avoidance of vague terms or superfluous words, keeping sentences clear and focussed.

- Paragraphs that are distinct enough to explore and evaluate a clear issue but linked well enough to enhance the flow of the thesis. A general rule of thumb is that a paragraph should be about half a page: any less and there is limited criticality, any longer and there is a tendency to ramble, lose focus and cause the reader to become disengaged.

- A PhD is not about how much the student can write: it is about how well they articulate and critically analyse information.

Critical writing at Doctoral level is essential to establish the quality of the research and the credibility of the researcher. A good thesis creates a portrait of an authoritative and competent researcher, and critical writing is crucial for building the examiners' confidence in the research undertaken.

\section{Publishable standard of the work}

Publishing in refereed journals and conferences is the traditional way in which the research community disseminates findings and builds knowledge, although there is increasing recognition of the role of social media platforms as a means of rapidly sharing knowledge. 
Table 1 Key principles to PhD study success

\begin{tabular}{|c|c|c|}
\hline The study & The thesis & Defence and the viva \\
\hline $\begin{array}{l}\text { Auditable, clear rationale of } \\
\text { purpose, question, aims and } \\
\text { methods: contribution to } \\
\text { knowledge needs to be unique and } \\
\text { show originality. } \\
\text { Well-articulated conceptual/ } \\
\text { theoretical framework. } \\
\text { Issues of ethics considered for both } \\
\text { studying the topic and how the } \\
\text { study is undertaken. } \\
\text { Evidence of quality appraisal and } \\
\text { reflexivity where appropriate. } \\
\text { Clear development of ideas-the } \\
\text { initial proposal is usually not the } \\
\text { final study. }\end{array}$ & $\begin{array}{l}\text { Title conveys what the study is about-do not } \\
\text { over complicate. } \\
\text { Abstract is well-structured, briefly outlines the } \\
\text { issue and methods and key findings; easily } \\
\text { conveyed to a non-expert audience. } \\
\text { Structures and flow of chapters } \\
\text { It is clear to the reader what contribution the } \\
\text { thesis is making. } \\
\text { Well justified question. } \\
\text { Well articulated methodology and application } \\
\text { of methods. } \\
\text { Discussion and conclusion enables the } \\
\text { reader to understand how research answered } \\
\text { the question/aims and is cognisant of the } \\
\text { methodological choices. } \\
\text { No overuse of appendices or footnotes. }\end{array}$ & $\begin{array}{l}\text { Convey passion for subject and methods. } \\
\text { Can articulate what has been undertaken, } \\
\text { what and why decisions were made. } \\
\text { Consideration of how, and in what other } \\
\text { ways, the subject/area of interest could } \\
\text { have been addressed-demonstration of } \\
\text { the ability to be self-critical. } \\
\text { Clear articulation of the contributions to } \\
\text { knowledge but also awareness of the field } \\
\text { and what others are doing. } \\
\text { A considered trajectory of what further } \\
\text { research is needed and would add to } \\
\text { understanding the problem/issues. } \\
\text { A considered trajectory of publication. }\end{array}$ \\
\hline
\end{tabular}

Refereed journals use recognised standards (such as the CONSORT (Consolidated Standards of Reporting Trials) guidelines for trials) ${ }^{5}$ and rigorous review processes to assess the quality of a research paper, which must be met for successful publication. It is therefore unsurprising that many examiners view a thesis more favourably if a student provides evidence of having published elements of their work. ${ }^{6}$

\section{Summary of key considerations}

Unlike undergraduate assessment, there is a paucity of research exploring the assessment of PhDs. However, a study that explored the process and judgements of experienced examiners, ${ }^{6}$ provided a valuable summary of the characteristics of a poor and excellent thesis (table 2).

\section{Conclusion}

This article has outlined some of the steps that a $\mathrm{PhD}$ student should consider in order to produce a highquality thesis and ensure a successful viva. We have considered how it is important that decision-making

\begin{tabular}{|c|c|}
\hline Poor thesis & Excellent thesis \\
\hline $\begin{array}{l}\text { Lack of coherence. } \\
\text { Lack of understanding of the } \\
\text { theory. } \\
\text { Lack of confidence. } \\
\text { Researching the wrong } \\
\text { problem. } \\
\text { Mixed or confused theoretical } \\
\text { perspectives. } \\
\text { Mixed or confused } \\
\text { methodology and methods. } \\
\text { Research poorly conducted. } \\
\text { Research not original. } \\
\text { Unable to articulate key } \\
\text { findings/implications of } \\
\text { findings. }\end{array}$ & $\begin{array}{l}\text { Excellent artistic endeavour. } \\
\text { Elegance of design, synthesis } \\
\text { and executions of the } \\
\text { research. } \\
\text { Creativity and originality } \\
\text { evident throughout. } \\
\text { Well-articulated problem, } \\
\text { question/aims. } \\
\text { Methodology seamless and } \\
\text { cohesive. } \\
\text { Rigorous application of } \\
\text { methods. } \\
\text { Well-sculpted thesis. }\end{array}$ \\
\hline
\end{tabular}

is transparent in the thesis, and defendable in the oral defence/viva. A PhD thesis should show evidence of originality and theoretical/conceptual cohesiveness, communicated via the student's critical writing ability. The thesis and defence provide students with the opportunity to share their knowledge and expertise in the field, offers them a methodological stage and gives the platform to share their critical perceptions, experiences and expertise.

Twitter David Barrett @barrett1972, Alison Rodriguez @ARodriguez339 and Joanna Smith@josmith175

Competing interests None declared.

Provenance and peer review Commissioned; internally peer reviewed.

( $)$ Author(s) (or their employer(s)) 2021. No commercial re-use. See rights and permissions. Published by BMJ.

\section{ORCID iDs}

David Barrett http://orcid.org/0000-0003-4308-4219

Alison Rodriguez http://orcid.org/0000-0001-91041999

\section{References}

1 Rodriguez A, Smith J, Barrett D. What are the foundations of a good PHD? Evid Based Nurs 2020;23:94-6.

2 Rüger S. How to write a good PHD thesis and survive the VIVA. UK: The Open University, 2016.

3 Fergie G, Beeke S, McKenna C, et al. It's a Lonely Walk: Supporting Postgraduate Researchers through Writing. Int $J$ Technol Learn High Edu 2011;23:236-45.

4 Wellington J. Making supervision work for you. London: Sage, 2010.

5 Campbell MK, Elbourne DR, Altman DG, et al. Consort statement: extension to cluster randomised trials. $B M J$ 2004;328:702-8.

6 Mullins G, Kiley M. 'It's a PhD, not a Nobel Prize': How experienced examiners assess research theses. Studies in Higher Education 2002;27:369-86. 